\title{
R\&D Investment and Patent Application: The Effects of Internationalization and Ownership
}

\author{
Francis Boadu ${ }^{1,2}$, Hongjuan Tang ${ }^{3}$ and $Y u \mathrm{Xie}^{4}{ }^{*}$ \\ ${ }^{1}$ School of Management and Economics, University of Electronic Science and Technology of China, \\ Chengdu 611731, China \\ ${ }^{2}$ Faculty of Entrepreneurship and Enterprise Development, Kumasi Technical University, Kumasi, \\ Ghana \\ ${ }^{3}$ School of economics and management, chongqing jiaotong university, Chongqing 400067, China \\ ${ }^{4}$ School of Management, Chongqing Technology and Business University, Chongqing 400067, China
}

\begin{abstract}
The purpose of this paper is to assess whether research and development (R\&D) investment, degree of internationalization (DOI), and ownership structure affect the patent application of enterprises in an emerging market. Using a firm-level data from 242 China's information and communication technology (ICT) and automobile manufacturing listed companies on Shanghai and Shenzhen A- stock exchanges market from 2011 to 2015, our empirical results demonstrate that: (1) the degree of internationalization of enterprises has a positive facilitating influence on the correlation among corporate R\&D investment and a patent application; (2) the state-owned ownership negatively moderates the R\&D investmentpatent application link, and (3) international expansion can adequately compensate for the efficiency disadvantages of R\&D investment and patent application engender by state ownership. Besides, the study discovered and explained an exciting phenomenon and bring forth important enlightenment to enterprises in the emerging economies to improve resource utilization efficiency and achieve technical ability to catch up.

Keywords: R\&D investment, Innovation, Internationalization, Ownership; emerging economies
\end{abstract}

\section{Introduction}

Technological innovation is regarded as a critical driving element to enhance enterprises' sustainable competitive advantage, productivity, and growth [1]. If used appropriately, it can aid enterprises to become more successful and sustainable in today's competitive environment. For instance, most global giants or enterprises from advanced economies have benefited from technological innovation due to their consistent effort to pursue technological breakthroughs to address the consumption patterns of both citizenry and customers from the international arena. However, the situation may be quite different in emerging economies, especially in China. Intriguingly, the proponents of resource dependence believe that Chinese enterprises are backward in terms of technology, and therefore have disadvantages in the

\footnotetext{
* Corresponding author: xieyu@ctbu.edu.cn
} 
global market environment. Indeed, for Chinese enterprises to address and erase this perception towards achieving post-development technology, it is prudent for the enterprises (i.e., state or private) to improve the research and development (R\&D) resource utilization efficiency. In recent years, this phenomenon has led scholars to focus more on how the internal and external factors such as R\&D resource redundancy, foreign investment behavior, international expansion, absorptive capacity, ownership structure, institutional resources, managerial corruption, and governmental intervention of enterprises in emerging economies affect R\&D investment and innovation output towards sustainable development. These, prior studies from the extant literature, have exposed some of the factors affecting the R\&D investment-output relationship in the emerging economies.

However, there are still shortcomings in the current economic globalization that need further probing to unravel the exact impact among the variables. First, the above studies conducted by scholars focus on the internal governance of the enterprises, with scant attention paid to the variation of corporate innovation practices caused by the cross-border expansion of China's local "latecomers" in the context of resource dependence. Secondly, ownership and internationalization, as important factors affecting the positive correlation amongst R\&D investment and a patent application of local Chinese enterprises under the background of economic globalization, are often studied separately and lack the exploration of the interaction mechanism. Considerably, we argue that the complex interaction of these variables (i.e., ownership and internationalization) can play a vital and stimulating role in addressing the gap in prior research. Hence, the current study intends to explore the combined influences of ownership and internationalization on the R\&D investment-patent application relationship, in the following conditions: (i) the global competitive environment, and (ii) the change under different internationalization levels. Specifically, it seeks to answer the following: RQ1. Is the correlation among R\&D investment and patent application dependent on an enterprise's involvement in international expansion? RQ2. Does state-ownership negatively moderate the correlation between R\&D investment and patent application? RQ3. Does international expansion have a positive influence on the negative effects of stateownership on R\&D investment and patent application? Using firm-level data obtained from China's ICT and automobile manufacturing companies listed on Shanghai and Shenzhen Astock exchanges market from 2011 to 2015 .

\section{Research framework and hypotheses development}

\subsection{Research framework}

The logical framework of the study is depicted in Figure 1. Admittedly, the current study contends that the correlation among R\&D investment and patent application is conditional upon ownership and international expansion. Consequently, the variables need to be jointly analyzed. We engage patent application as output indicators for R\&D investment, and comprehensively explores the combined effect of ownership and internationalization on the R\&D investment-patent application links to established the clear correlation mechanism among them. The next section discusses the model and the related hypotheses. 


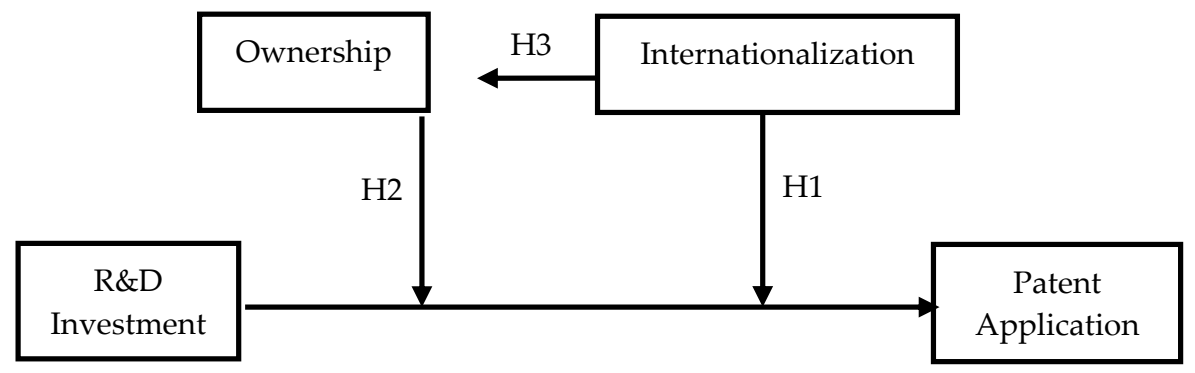

Fig. 1. Research Framework.

\subsection{The impact of internationalization on the association among R\&D investment and patent application}

Internationalization is an essential strategy for emerging market enterprises to achieve technological catch-up and enhance the R\&D investment output of enterprises [12]. Unlike developed-economy multinational enterprises, Chinese multinational enterprises need to obtain external heterogeneous resources, advanced technologies, and knowledge for the application of patent innovation in overseas markets. Concurrently, enterprises can organize and learn in the process of internationalization to rapidly improve their innovation abilities to gain market shares as well as a competitive advantage. The reflection of the positive impact among the three variables (i.e., internationalization, $R \& D$ investment, and corporate patent applications) is in the following aspects:

First, international expansion can aid enterprises in obtaining external heterogeneous innovation resources, which can provide direction for technology [13], thereby promoting the efficiency of R\&D investment. For instance, information resources, R\&D personnel, lowpriced material, and R\&D alliances. As a latecomer entrant to the global economy market arena, emerging economies have very scarce resources in both technology and market [14]. Admittedly, in terms of industrial and technological infrastructure development, emerging economies are far from the global science and technology centers. They also have a disadvantage in terms of accessibility to technical talent resources, innovative information resources, and participation in innovative $R \& D$ alliances [15]. These critical restrictions have made it impossible for them to seek resources from the domestic market. Nevertheless, international expansion can help enterprises from emerging economies to obtain low-cost raw materials, labor or tax incentives, and other resources for the reduction of R\&D costs [5]. Simultaneously, the international market can encourage enterprises to obtain technical resources that are not available in their home country (e.g., China), but have the potential to help them improve the efficiency of R\&D patent output in order to occupy broader market space. Interestingly, when the degree of internationalization of enterprise is low, it is problematic for the enterprise to benefit from R\&D investment in a limited market [13]. Conversely, when the degree of internationalization of enterprise is high, the broader market space can effectively share the R\&D risk caused by the economic fluctuation of the individual market or the product life cycle, thereby helping enterprises improve the productivity of $\mathrm{R} \& \mathrm{D}$ investment.

Second, international expansion can promote innovative learning on a global scale. Organization learning refers to a process by which an enterprise acquires, absorbs, digests, and applies new knowledge (i.e., external knowledge) about its environment, goals, and processes [16]. The expansion process of internationalization creates an avenue for latecomers to learn from advanced foreign knowledge and experience, cultural intelligence, as well as cross-cultural management to enhance their innovative R\&D capabilities. The international market has vast differences (especially with the home market) in terms of 
resource endowment, technical knowledge, managerial skills, and cultural diversification. The difference has brought a certain degree of negative impact on the enterprise's international expansion strategy. Equally, it has also provided a variety of learning objects for international enterprises, through communication and exchange, learning and imitation, and competition and cooperation with more regions or countries. We believe that it can enhance local enterprises' in-depth understanding of advanced overseas enterprises. Enterprises learning in diversified international environment gain diverse knowledge and innovation experiences to promote their rapid identification of innovation opportunities. Xie, $\mathrm{Du}$, Boadu, and Shi [14] assert that apart from the provision of innovative resources and learning opportunities for enterprises, international expansion can help enterprises to build capability for opportunity identification and opportunity utilization. They also emphasize that enterprises in emerging economies not only learn technology and innovation experience from advanced enterprises in the process of internationalization, but they (enterprises) as well enhanced their knowledge creation performance through reserve knowledge transfer [6], which, in turn, promotes the unit output of enterprises' R\&D investment. Hence, we argue that enterprises in emerging economies have benefited from accessing external heterogeneous resources and learning advanced, diversified innovation knowledge and experience through international expansion, thereby promoting unit output of R\&D investment. Formally, we propose the following hypothesis: Hypothesis 1 (H1). Internationalization positively moderates the effects of R\&D investment and patent application.

\subsection{The influence of ownership on the association among R\&D investment and patent applications}

Prior studies on SOEs and POEs have revealed significant differences in their innovation activities [4]. These two enterprises are associated with different types of ownership; the government / the country owned and controlled the former, whereas an individual or partner owned the latter. From their innovation activities, it is clear that the effects of R\&D investments are significantly dissimilar. The impact of corporate ownership in emerging economies on R\&D investment output is mainly due to the following aspects:

First, drawing on an agency theory, the separation of ownership and management can create an agency problem. Compared with private enterprises, the agency problem in SOEs is more prominent. In principle, the ownership of SOEs belongs to the entire citizenry of a country. Moreover, there is no real agent and trustee relationship. If the state's supervision mechanism is not perfect, it may be challenging to ensure that the agent will not seek personal gain because of his position [17]. Also, the promotion of senior executives in the SOEs is closely linked to the business performance of the enterprise as well as the political goals of the government. In the pursuance of innovative patents with significant investment, long cycle, and high risk, senior executives in the state-owned enterprises intend to circumvent for hunting such a market-oriented and efficiency-based innovative R\&D activity. However, they prefer to implement such opportunities when available in their enterprises. These administrative duties can result in inefficient use of R\&D investment [1].

Second, it should be noted that in the state-owned enterprises, political identity is vital for the "convenience conditions" needed to innovate [2]. However, a lot of factors (such as market structure, product structure, technology strategy, technology platform, among others) in non-political identity also serve as a critical element for the realization of state-owned enterprise innovation [18]. Su [19] asserts that the pressure on the executives of state-owned enterprises mainly stems from the market, but the competent authorities. Indeed, it reduces the degree of concern of managers for non-political status, and thus forms a disadvantage of ownership in the innovation efficiency of SOEs. Moreover, state-owned assets holding 
enterprises usually have internal governance issues such as insufficient resources, managerial corruption, and governmental intervention regarding their administration. These factors have led to inefficient resource allocation. For instance, in state-owned enterprises, the low efficiency of resource allocation makes R\&D investment intensity low in terms of innovation performance. Albeit, state-owned assets holding enterprises can support enterprises to obtain more external resources but will hurt innovation efficiency. Formally, we propose the following hypothesis: Hypothesis 2 (H2). State-owned ownership negatively moderates the correlation between R\&D investment and patent application.

\subsection{The effect of internationalization on the disadvantage of ownership}

The management of $R \& D$ differs among different ownership types of enterprises. Simultaneously, these differences are affected by the degree of internationalization. We argue that the international expansion of enterprises in emerging economies is conducive to avert the disadvantages of ownership and accelerate the technological catch-up process of stateowned enterprises, thereby increasing the unit output of R\&D investment. We elucidate the two main aspects in detail below:

First, from the perspective of internal operations of enterprises, with the deepening of internationalization, state-owned enterprises have realized management modernization and global talent management through international expansion. The process can eventually enable enterprises to make up to some extent the corruption, inaction, and long-term investment commitment of managers in the R\&D activities of state-owned enterprises. Thus, promoting the efficiency of $R \& D$ input and patent output. As the degree of internationalization increases, companies face fierce competitive pressures leading to higher uncertainty, which eventually lands them to the entrusted agency problems. Therefore, it is essential to improve the incentive mechanism through the adoption of quality management practices and the implementation of effective ways of utilizing resources to ensure that companies enjoy a competitive edge in the global market arena.

Second, from the perspective of external resource utilization, enterprises can obtain vital resources through overseas subsidiaries [20], and transfer these resources to the home country enterprises, to some extent. Such high resources have made up for the problem of the insufficient innovation capacity of state-owned enterprises.

Indeed, emerging market enterprises can enter advanced overseas markets in the process of internationalization, and learn technology, management, operations, and other knowledge, and eventually transfer back to the home country enterprises, which, is conducive to alignment or make up for the weak innovation system in the home country [21]. Precisely, under the conditions of the same scale of the enterprise, the higher the proportion of overseas sales to total sales, the more patent application the enterprise may obtain [22]. Therefore, enterprises actively formulate and implement the strategy of going global, which is conducive to improving the unit output of state-owned enterprises' R\&D investment.

Consequently, we argue that state-owned enterprises in emerging economies can be managed to acquire various resources and capabilities essential for innovation through international expansion, thereby diminishing the ownership disadvantages caused by stateowned enterprises. Formally, we propose the following hypothesis: Hypothesis 3 (H3). The negative effects of state ownership on $R \& D$ investment and patent application will be weakened through internationalization. 


\section{Method}

\subsection{Data and sample}

Our study focused on the empirical analysis of secondary data. We selected manufacturing industries from ICT and automobiles as our research objects among all A-share listings on the Shanghai and Shenzhen Stock Exchange for the period 2011-2015. We collected data on various variables from the CSMAR, WIND database (which are a popular and authoritative database in China in terms of information), and an annual report of listed companies (mainly used to supplement missing data). We obtained 1450 samples from 319 companies. Then, following the rules, we eliminated companies with missing data. As a result, we recorded 1193 valid samples. In all, out of the 319 companies, 242 companies were from the ICT industry, and 77 companies were from the automobile manufacturing industry.

\subsection{Measures}

\subsubsection{Dependent variable}

The study adopted a patent application as a dependent variable. To measure the variable, we collected data from the CSMAR database, spanning from the period 2011 to 2015.

\subsubsection{Independent variable}

The study adopted R\&D investment as an independent variable. We used data obtained from the WIND database to measure the variable. Also, due to the changes in a certain period of $\mathrm{R} \& \mathrm{D}$ investment to the patent application, all independent variables are lagged one year to avoid reverse-causality.

\subsubsection{Moderating variables}

In this study, we have two moderating variables in our statistical model. The variables are internationalization and ownership, respectively. First, we used the ratio of overseas operating income to total operating income as a measure of the DOI. We obtained the data from the WIND. Second, concerning existing studies [23], we consider two dummy variables zero and one as a measure to the ownership characteristics. The value of the state-owned enterprise is 1 , and vice versa is 0 . We obtained the data from the CSMAR database.

\subsubsection{Control variables}

We used enterprises' size, age, net profit, the separation of ownership and management, and the industry types as control variables. Based on existing studies, these variables have a significant influence on the internationalization process and technological innovation efficiency [24-26]. The study obtained the information for age and net profit of the companies from the WIND database, whereas, CSMAR database provided data to measure for the scale of the separation of ownership and management, as well as industry types. Besides, the study used the number of workforces to measure the enterprises' size. In summary, the variables of the study are depicted in Table 1. 
Table 1. Variables and measurements.

\begin{tabular}{|c|c|c|c|}
\hline \multicolumn{2}{|c|}{ Variable } & \multirow[t]{2}{*}{ Measurement } & \multirow{2}{*}{$\begin{array}{c}\text { Data } \\
\text { Sources } \\
\text { CSMAR }\end{array}$} \\
\hline Dependent variable & Patent application & & \\
\hline $\begin{array}{c}\text { Independent } \\
\text { variable }\end{array}$ & R\&D investment & Last year's R\&D investment & Wind \\
\hline \multirow{2}{*}{ Moderator variable } & $\begin{array}{c}\text { Internationalization } \\
\text { Degree }\end{array}$ & $\begin{array}{l}\text { Overseas revenue as a percentage of } \\
\text { total revenue }\end{array}$ & Wind \\
\hline & Ownership & $\begin{array}{c}\text { State-owned enterprises are 1; private } \\
\text { enterprises are } 0\end{array}$ & CSMAR \\
\hline \multirow{5}{*}{ Control variable } & Enterprise size & Number of workforces & Wind \\
\hline & Age & Year of the establishment - 2015 & Wind \\
\hline & Separation & - & CSMAR \\
\hline & Industry & $\begin{array}{l}\text { ICT industry value } 1 \text {, automotive } \\
\text { manufacturing value } 0\end{array}$ & CSMAR \\
\hline & Net profit & - & Wind \\
\hline
\end{tabular}

\section{Empirical results}

\subsection{Mean, standard error, pearson intercorrelations matrix}

Tables 2 reports the mean, S.E, and Pearson intercorrelation matrix of the constructs. The results from Table 2 demonstrate a positive association among R\&D investment and patent application $(\beta=0.589, \mathrm{P}<0.01)$. It also reveals that enterprise size $(\beta=0.738, \mathrm{P}<0.01)$ and net profit $(\beta=0.663, \mathrm{P}<0.01)$ have a significant correlation with $\mathrm{R} \& \mathrm{D}$ investment. Besides, we conducted OLS regression on all the models involved in the study to avoid the collinearity problem. Our results show that the VIF values in all models are less than 10, so it can be inferred that there is no obvious multicollinearity in each model of the study 
Table 2. Mean, standard error, and correlational relationship among constructs (Cov).

\begin{tabular}{|c|c|c|c|c|c|c|c|c|c|c|c|}
\hline Variables & Mean & S.E & 1 & 2 & 3 & 4 & 5 & 6 & 7 & 8 & 9 \\
\hline $\begin{array}{l}\text { 1.Patent } \\
\text { application }\end{array}$ & 40.31 & 224.69 & 1 & & & & & & & & \\
\hline $\begin{array}{l}\text { 2. R\&D } \\
\text { investment } \\
\text { (million) } \\
\text { 3. }\end{array}$ & 190 & 596 & $\begin{array}{l}.589 \\
* *\end{array}$ & 1 & & & & & & & \\
\hline $\begin{array}{l}\text { Internationa } \\
\text { lization } \\
\text { Degree }\end{array}$ & 0.23 & 0.25 & $\begin{array}{l}.058 \\
*\end{array}$ & -.001 & 1 & & & & & & \\
\hline $\begin{array}{l}4 . \\
\text { Ownership }\end{array}$ & 0.32 & 0.46 & $\begin{array}{l}.088 \\
* *\end{array}$ & $\begin{array}{l}.181 \\
* *\end{array}$ & $\begin{array}{l}-.136 \\
* *\end{array}$ & 1 & & & & & \\
\hline $\begin{array}{l}\text { 5. Size } \\
\text { (thousand) }\end{array}$ & 6.25 & 16.07 & $\begin{array}{l}.344 \\
* *\end{array}$ & $\begin{array}{l}.738 \\
* *\end{array}$ & .018 & $\begin{array}{l}.145 \\
* *\end{array}$ & 1 & & & & \\
\hline 6. Age & 16.72 & 4.80 & $\begin{array}{l}.070 \\
*\end{array}$ & $\begin{array}{l}.067 \\
*\end{array}$ & .030 & $\begin{array}{l}.331 \\
* *\end{array}$ & $\begin{array}{l}.103 \\
* *\end{array}$ & 1 & & & \\
\hline $\begin{array}{l}7 . \\
\text { Separation } \\
\text { rate }\end{array}$ & 4.40 & 7.34 & $\begin{array}{l}.065 \\
*\end{array}$ & .041 & -.043 & $\begin{array}{l}.061 \\
*\end{array}$ & .016 & $\begin{array}{l}.094 \\
* *\end{array}$ & 1 & & \\
\hline 8. Industry & 0.76 & 0.42 & .004 & $\begin{array}{l}-.170 \\
* *\end{array}$ & $\begin{array}{l}.224 \\
* *\end{array}$ & $\begin{array}{l}-.134 \\
* *\end{array}$ & $\begin{array}{l}-.184 \\
* *\end{array}$ & $\begin{array}{l}-.03 \\
8\end{array}$ & $\begin{array}{l}-.172 \\
* *\end{array}$ & 1 & \\
\hline $\begin{array}{l}\text { 9. Net profit } \\
\text { (million) }\end{array}$ & $\begin{array}{l}342.7 \\
6\end{array}$ & $\begin{array}{l}1791.0 \\
2\end{array}$ & $\begin{array}{l}.081 \\
* *\end{array}$ & $\begin{array}{l}.663 \\
* *\end{array}$ & $\begin{array}{l}-.071 \\
*\end{array}$ & $\begin{array}{l}.141 \\
* *\end{array}$ & $\begin{array}{l}.530 \\
* *\end{array}$ & .019 & .010 & $\begin{array}{l}-.194 \\
* *\end{array}$ & 1 \\
\hline
\end{tabular}

$\mathrm{P}<0.05 *, \mathrm{P}<0.01 * *$ (Two-tailed), $\mathrm{N}=119$ 
Table 3. Regression results and robustness test

\begin{tabular}{|c|c|c|c|c|c|c|c|}
\hline \multirow{2}{*}{ Variable/model } & \multicolumn{4}{|c|}{ Fixed effect model (M1-M4) } & \multicolumn{3}{|c|}{ 2SLS (M2a-M4a) } \\
\hline & M 1 & M 2 & M 3 & M 4 & M2a & M3a & M4a \\
\hline Size & $0.424(0.032)^{* * *}$ & $-0.143(0.03)^{* * *}$ & $-0.004(0.028)$ & $-0.177(0.03)^{* * *}$ & $-0.576(0.04)^{* * *}$ & $-0.037(0.19)$ & $\overline{0}-592(0.039)^{* * *}$ \\
\hline Age & $0.024(0.027)$ & $0.02(0.02)$ & $0.04(0.018)^{*}$ & $0.023(0.021)$ & $0.022(0.024)$ & $0.042(0.02)^{*}$ & $0.038(0.025)$ \\
\hline Separation rate & $0.068(0.028)^{*}$ & $0.035(0.02)$ & $0.019(0.018)$ & $0.026(0.02)$ & $0.014(0.025)$ & $0.021(0.018)$ & $0.005(0.024)$ \\
\hline Industry & $0.16(0.066)^{*}$ & $0.137(0.049)^{* *}$ & $0.055(0.045)$ & $0.131(0.048)^{* *}$ & $0.128(0.059)^{*}$ & $0.064(0.055)$ & $0.112(0.058)^{*}$ \\
\hline Net profit & $-0.132(0.032)^{* * *}$ & $\begin{array}{l}- \\
0.537(0.027)^{* * *}\end{array}$ & $-0.087(0.037)^{*}$ & $-0.413(0.035)^{* * *}$ & $\begin{array}{l}- \\
0.841(0.035)^{* * *}\end{array}$ & $-0.134(0.285)$ & $\begin{array}{l}- \\
0.678(0.044)^{* * *}\end{array}$ \\
\hline $\begin{array}{l}\text { Internationalization } \\
\text { Degree }\end{array}$ & & & $0.052(0.019)^{* *}$ & & & $0.049(0.028)^{*}$ & \\
\hline Ownership & & & & $-0.007(0.021)$ & & & $-0.047(0.026)$ \\
\hline R\&D investment & & $1.062(0.033)^{* * *}$ & $0.632(0.04)^{* * *}$ & $1.069(0.033)^{* * *}$ & $1.863(0.052)^{* * *}$ & $0.701(0.423)^{* * *}$ & $1.831(0.05)^{* * *}$ \\
\hline $\begin{array}{l}\text { R\&D investment } \times \\
\text { Internationalization } \\
\text { Degree }\end{array}$ & & & $0.461(0.029)^{* * *}$ & & & $0.428(0.200)^{* * *}$ & \\
\hline $\begin{array}{l}\text { R\&D investment } \times \\
\text { Ownership }\end{array}$ & & & & $-0.132(0.025)^{* * *}$ & & & $-0.154(0.03)^{* * *}$ \\
\hline Cons. & $-0.122(0.057)^{*}$ & $-0.104(0.042)^{*}$ & $-0.041(0.039)$ & $-0.076(0.042)$ & $-0.098(0.051)$ & $-0.048(0.046)$ & $-0.058(0.051)$ \\
\hline R2 (within) & 0.148 & 0.538 & 0.621 & 0.548 & $\begin{array}{l}0.305 \\
\text { (Centered) }\end{array}$ & $\begin{array}{l}0.618 \\
\text { (Centered) }\end{array}$ & 0.339 (Centered) \\
\hline $\mathrm{F}$ & $39.080^{* * *}$ & $229.040^{* * *}$ & $241.970 * * *$ & $179.070^{* * *}$ & $249.63^{* * *}$ & $209.74 * * *$ & $200.96^{* * *}$ \\
\hline Anderson canon. corr & LM statistic & & & & $719.575^{* * *}$ & $392.352 * * *$ & $760.415^{* * *}$ \\
\hline Cragg-Donald Wald $\mathrm{H}$ & statistic & & & & 900.560 & 289.861 & 1039.762 \\
\hline Sargan statistic & & & & & 0.39 & 0.47 & 0.63 \\
\hline
\end{tabular}

$\mathrm{P}<0.05 *, \mathrm{P}<0.01 * *, \mathrm{P}<0.001 * * *, \mathrm{~N}=1193$, (Two-tailed), Coef. (S.E) 


\subsection{Hypotheses testing}

In this study, we used unbalanced panel data, and mixed OLS regression does not eliminate the interference because the year change has on the regression results. Especially when the same enterprise incorporates repeated observation data across years, it is advisable to use panel data processing methods [4]. At the same time, two categories of models, namely, the fixed-effects model and random-effects model, respectively, in the model selection. Our Hausman test results from M1-M4 show that P-value is $>0.05$; therefore, we rejected the original hypothesis. This result demonstrates that the unobserved individual effects are related to the individual effects observed in the model. Thus, the fixed-effect model is selected. Tables 3 and 4 show the results of regression analysis (i.e., the fixed-effects regression analysis). First, Model 1 of Table 3 captures all control variables of the study $(\mathrm{F}=39.080, \mathrm{P}(\mathrm{F})<0.001, \mathrm{R} 2=0.148)$.

Second, the results in M2 show that the enterprise's R\&D investment has a statistically significant and positive impact on patent application $(\beta=1.062, \mathrm{P}<0.001$ ), which is consistent with the results of most previous studies.

Third, from Table 3, M3, our findings establish that the degree of internationalization of enterprises has a positive moderating effect on the correlation among $R \& D$ investment and patent applications ( $\beta=0.461, P<0.001$ ). The results indicate that with the intensification of international expansion, the same unit of $R \& D$ investment of enterprises can bring more patent applications. Thus, hypothesis 1 is verified.

Third, the interaction term between research and development investment and stateowned ownership has a negative influence on patent applications $(\beta=-0.132, \mathrm{P}<0.001)$ (see Table 3, M4). Compared with private enterprises, the results indicate that the R\&D investment output efficiency of SOEs is low. Thus, hypothesis 2 is verified. To further explore the far-reaching influence of DOI and ownership on the correlation among R\&D investment and output, this study further explored in groups.

In Table 4, the study divided the sample companies into two groups according to the degree of internationalization, and also separated the groups into SOEs and POEs. Then, the study formed four sets of data, namely: low internationalization level \& SOEs (model M5); low internationalization level \& POEs (model M6); high internationalization level \& SOEs (model M7); High internationalization level \& POEs (model M8). Table 4 reports the impact factors of R\&D investment on patent applications in each group. Our results concerning low internationalization show a big gap between SOEs and POEs (see, Table 4). First, the positive effect of R\&D investment of SOEs on a patent application $(\beta=0.423, \mathrm{P}<0.001$, in model M5), is much smaller than that of POEs ( $\beta=0.858$; $\mathrm{P}<0.001$; in model M6). Second, the positive effect of $R \& D$ investment of SOEs to a patent application $(\beta=1.109, P<0.001$, in model M7) is more significant and is close to the index of POEs $(\beta=1.169, \mathrm{P}<0.001$, in model M8). The results demonstrate that spiraling of internationalization can pay-off ownership disadvantage experienced by Chinese enterprises. Thus, hypothesis 3 is verified. 
Table 4. Regression result by group.

\begin{tabular}{|c|c|c|c|c|}
\hline \multirow[b]{2}{*}{ Variable/model } & \multicolumn{2}{|c|}{ Lower internationalization M5-M6 (596 firms) } & \multicolumn{2}{|c|}{$\begin{array}{l}\text { Higher internationalization M7-M8(597 } \\
\text { firms) }\end{array}$} \\
\hline & $\begin{array}{l}\text { M5 } \\
\text { state-owned enterprises }\end{array}$ & $\begin{array}{l}\text { M6 } \\
\text { private enterprises }\end{array}$ & $\begin{array}{l}\text { M7 } \\
\text { state-owned } \\
\text { enterprises }\end{array}$ & $\begin{array}{l}\text { M8 } \\
\text { private enterprises }\end{array}$ \\
\hline Size & $0.117(0.040) * *$ & $0.521(0.123) * * *$ & $-0.207(0.213)$ & $0.084(0.066)$ \\
\hline Age & $-0.045(0.033)$ & $-0.342(0.103)$ & $0.199(0.1) *$ & $0.022(0.028)$ \\
\hline Separation rate & $0.029(0.026)$ & $0.215(0.087)$ & $-0.031(0.118)$ & $0.028(0.028)$ \\
\hline Industry & $0.085(0.067)$ & $0.699(0.214) *$ & $0.592(0.363)$ & $-0.026(0.07)$ \\
\hline Net profit & $-0.290(0.044) * * *$ & $-0.509(0.134) * * *$ & $0.069(0.262)$ & $-0.674(0.123) * * *$ \\
\hline $\begin{array}{l}\mathrm{R} \& \mathrm{D} \\
\text { investment }\end{array}$ & $0.423(0.064) * * *$ & $0.858(0.198) * * *$ & $1.109(0.214) * * *$ & $1.169(0.037) * * *$ \\
\hline Cons. & $-0.048(0.050)$ & $1.864(0.160)$ & $-0.618(0.342)$ & $0.061(0.063)$ \\
\hline R2 & 0.249 & 0.315 & 0.308 & 0.208 \\
\hline $\mathrm{F}$ & $11.42 * * *$ & $14.53 * * *$ & $10.91 * * *$ & $76.69^{* * *}$ \\
\hline $\mathrm{N}$ & 218 & 378 & 158 & 439 \\
\hline
\end{tabular}

$\mathrm{P}<0.05 *, \mathrm{P}<0.01 * *, \mathrm{P}<0.001 * * *$ (Two-tailed), Coef. (S.E)

\subsection{Model robustness check}

From the extant literature, scholars attest that endogeneity is a problem that cannot be wholly solved, especially in a panel data analysis for empirical studies. Indeed, endogenous problems in the field of strategic management have received more attention in the literature. Hence, we employed a two-stage least square (2SLS) method to assess the endogeneity of the study. Some authors have pointed out that the 2SLS (two-stage least squares) method is an effective way to correct the endogeneity in the panel data model [27]. The current study considers that the company's research and development capabilities and government subsidies can easily interfere with the correlation among research and development investment and patent application. We utilized the factors as instrumental variables into the 2SLS model for regression.

Table 3 presents the regression results for 2SLS (i.e., values of Model 2a-Model 4a) and the fixed effect model (i.e., values of Model 1-Model 4). From the table, the results for the 2SLS analysis are consistent with the corresponding fixed-effect model results (i.e., from Model 2-Model 4).

At the same time, the study follows [4] and the Stata tutorial to test the validity of the instrumental variables used in the 2SLS model. These include the under-identification test, weak identification test, and over-identification test. First, our findings from Table 3 show that the Anderson-LM statistic of each model of 2SLS is significant $(\mathrm{P}<0.001)$, rejecting the null hypothesis of under-identification. Secondly, the Cragg-Donald Wald F statistic is greater than 10 (i.e., the instrumental variable and the endogenous variable have a strong correlation, indicating that the study is suitable for weak identification tests). Thirdly, the Sargan statistic report is not significant $(\mathrm{P}>0.05)$, suggesting that there is no overidentification problem. Furthermore, the regression results of the above 2SLS model are consistent with the initial results obtained by the fixed effect model. These findings provide evidence that the conclusion of this study is robust. 


\section{Discussion and conclusion}

In today's ever-changing dynamic environment, innovation has become a lifeblood for firms to accomplish their strategic vision and objectives. Admittedly, firms that posse innovation prowess performs tremendously in the market environment. Interestingly, research and development cannot be ignored in the firm's patent applications. Many firms across the globe spend huge resources on research and development activities to enhance their patent application in order to perform better in the international market arena. Surprisingly, in the extant studies, few scholarships have been executed to examine the stimulating role of research and development investment on the patent application of enterprises from emerging economies. Explicitly, the facilitating influence of DOI and ownership on the linkage between research and development investment and patent application. The current scholarship constructed a logical model to better comprehend the circumstance under which research and development investment influences the patent application of enterprises in China. The findings emanating from the current study have important theoretical implications. First of all, this study explores the influence of the degree of internationalization and ownership on the corporate R\&D investment-patent application links. The extant research has paid much attention to the impact of ownership [2-4] and international expansion [5, 6] on innovation performance, but has not reached a consensus conclusion. The main reason may be that ownership and international expansion are considered separately in different models, and the interaction between them is less considered. Based on the existing literature, this study carries out a comprehensive model test, which analyzes the influence mechanism of internationalization degree and ownership on the R\&D investment-patent application link.

Second, the current study reveals that internationalization can reduce the negative effect of SOE on the R\&D investment-patent application relationship. The unique behavior of Chinese companies in their international expansion is primarily due to their national ownership [7]. Scholars have paid attention to the influence of state ownership on international expansion activities of enterprises [8,9] and innovation efficiency $[10,11]$; however, few studies have focused on the changes in ownership disadvantages as companies continue to expand internationally. Hence, the study explores the changes in the association between state ownership and R\&D input and patent output at different levels of internationalization. Our findings demonstrate that the international expansion of enterprises can reduce the negative influence of state ownership on the efficiency of R\&D investment. Admittedly, the results indicate that appropriate international expansion of SOEs can compensate for the disadvantages of ownership. Besides, the study discovered and explained an exciting phenomenon and bring forth necessary enlightenment to enterprises in the emerging economies (i.e., represented by China) to improve resource utilization efficiency and achieve technical ability to catch up.

Our empirical results have crucial implications for practitioners and policymakers. First, executives should remain focus and apply all research outputs to address fluctuating market demands speedily. Secondly, policymakers should enact laws and regulations to set a threshold (i.e., lower and upper support limit) on research and development activities and encourage SOEs to adhere to it in their overall goals. Such laws and regulations can lead firms to develop robust innovation performance.

\section{Limitation}

This paper explores the influence of ownership and internationalization on the R\&D investment-patent application link in emerging market enterprises. We adopted the normative method for the study, but the following shortcomings still exist: First, in the sample selection, we considered only two industries, namely; ICT and automobile manufacturing, as samples. 
Our overall sample size is small, and the expansion of the industries may lead to further discoveries. Therefore, future research can consider a broader sample size to test the research model. Second, our study only explores the influence of the degree of internationalization and state ownership on the R\&D investment-patent application link. The perspective is relatively simple. There is no further discussion on the interference factors such as the monopoly of SOEs and the political purpose of the SOEs in the process of internationalization. We encourage future researchers to consider interference factors. Third, the study focused on China. A future study can examine the generalizability of our findings to other emerging economies.

\section{Acknowledgments}

This research was financially supported by the High level talents Research Foundation Project (No. 950319146); and National Natural Science Fund of China (No.71672021).

\section{References}

1. K. Z. Zhou, G. Y. Gao, H. Zhao, State Ownership and Firm Innovation in China: An Integrated View of Institutional and Efficiency Logics. Administrative Science Quarterly, 62, 2 (2017)

2. V. Z. Chen, J. Li, D. M. Shapiro, X. Zhang, Ownership structure and innovation: An emerging market perspective. Asia Pacific Journal of Management, 31, 1, 1-24 (2014)

3. P. Boeing, E. Mueller, P. Sandner, China's R\&D explosion-Analyzing productivity effects across ownership types and over time. Research policy, 45, 1, 159-176 (2016)

4. Y. Yang, J. Wei, L. Luo, Who is using government subsidies for innovation? - The joint adjustment effect of ownership and factor market distortions. Management world, 1,1, 75-86 (2015)

5. B. Hai, n. Nie, Internationalization, Innovation and Corporate Performance: An Empirical Study Based on Hubei Province. Scientific research management, 33, (4), 19 (2012)

6. L.H. Du, Creative asset seeking, subsidiary influence and reverse knowledge transfer. Scientific research management, 3, 39, 85-96 (2018)

7. R. Ramamurti, J. Hillemann, What is "Chinese" about Chinese multinationals? Journal of International Business Studies,49, 1, 34-48 (2018)

8. M. W. Peng, S. L. Sun, B. Pinkham, H. Chen, The institution-based view as a third leg for a strategy tripod. Academy of Management Perspectives, 23, 3, 63-81 (2009)

9. Y. Luo, R. L. Tung, A general theory of springboard MNEs. Journal of International Business Studies, 49, 2, 129-152 (2018)

10. K. Z. Zhou, G. Y. Gao, H. Zhao, State ownership and firm innovation in China: An integrated view of institutional and efficiency logics. Administrative Science Quarterly, 62, 2, 375-404 (2017)

11. X. Cao, D. J. Cumming, S. Zhou, State ownership and corporate innovation efficiency. Available at SSRN 2868036 (2018).

12. B. Hagen, S. Denicolai, A. Zucchella, International entrepreneurship at the crossroads between innovation and internationalization. Journal of International Entrepreneurship, 12, 2, 111-114 (2014) 
13. M. A. Hitt, R. E. Hoskisson, H. Kim, International diversification: Effects on innovation and firm performance in product-diversified firms. Academy of Management journal, 40, 4, 767-798 (1997)

14. Y. Xie, Y.-F. Du, F. Boadu, X.-Y. Shi, Executives' Assessments of Evolutionary and Leapfrog Modes: An Ambidexterity Explanation Logic. Sustainability,10,8,2893(2018)

15. J. A. Mathews, Dragon multinationals: New players in 21 st century globalization. Asia Pacific journal of management, 23, 1, 5-27 (2006)

16. W. M. Cohen, D. A. Levinthal, Absorptive capacity: A new perspective on learning and innovation. Administrative science quarterly, 12,1,1128-152 (1990)

17. A. I. Khwaja, A. Mian, Do Lenders Favor Politically Connected Firms? Rent Provision in an Emerging Financial Market. Quarterly Journal of Economics, 120, 4, 1371-1411 (2005)

18. J. Su, Q. Lin, Independent innovation of state-owned enterprises: What are the situational factors besides political identity? Management review, 28, 3, 230-240 (2016)

19. X. Su, Managers' Work Stressors and Their Impacts - Comparison between State-owned Enterprises and Private Enterprises. Management world, 2 (8), 105-113 (2005)

20. Y. Luo, R. L. Tung, International expansion of emerging market enterprises: A springboard perspective. Journal of international business studies, 38, 4, 481-498 (2007)

21. A. Madhok, M. Keyhani, Acquisitions as entrepreneurship: Asymmetries, opportunities, and the internationalization of multinationals from emerging economies. Global Strategy Journal, 2, 1, 26-40 (2012)

22. P. Zeng, T. Deng, The relationship between the degree of internationalization of enterprises and technological innovation: a perspective of learning. International trade issues, 3,10, 59-67 (2012)

23. M. Kotabe, S. S. Srinivasan, P. S. Aulakh, Multinationality and firm performance: The moderating role of R\&D and marketing capabilities. Journal of international business studies, 33, 1, 79-97 (2002)

24. E. Huergo, J. Jaumandreu, Firms' age, process innovation and productivity growth. International Journal of Industrial Organization, 22, 4, 541-559 (2004)

25. F. Damanpour, Organizational size and innovation. Organization studies, 13, 3, 375-402 (1992)

26. R. Ortega-Argiles, R. Moreno, J. S. Caralt, Ownership structure and innovation: is there a real link? The Annals of Regional Science, 39, 4, 637-662 (2005)

27. Y. Wang, H. Li, Endogenous problems and correction methods in management research. Management quarterly, 2, 3, 20-47 (2017) 